\title{
Students' Misconceptions on Understanding Corrosion Topic by and without Analogy
}

\author{
Findiyani Ernawati Asih \\ Departement of Chemistry \\ Universitas Negeri Surabaya \\ Surabaya, Indonesia \\ findiyaniasih@unesa.ac.id \\ Suyono \\ Departement of Chemistry \\ Universitas Negeri Surabaya \\ Surabaya, Indonesia \\ suyono@unesa.ac.id
}

\author{
Suhadi Ibnu \\ Departement of Chemistry \\ Universitas Negeri Malang \\ Malang, Indonesia \\ suhadi.ibnu.fmipa@um.ac.id \\ Suharti \\ Departement of Chemistry \\ Universitas Negeri Malang \\ Malang, Indonesia \\ suharti.fmipa@um.ac.id
}

\begin{abstract}
Redox reactions is spontaneous which can produce electrons flow. This condition can make corrosion of ferrum metal.. The electrons flow is not observed (submicroscopic aspect), so requires visualization. Strategy for visualizing submicroscopic aspect is analogy learning. The electrons flow can be analogous by the flow of waterfall. This research aims to examine the effect of analogy on the achievement of students' understanding. The research used quasy experiment method with a nonequivalent posttest only control group design, so that there were an inquiry class by analogy (ICBA) and an inquiry class without analogy (ICWA). The results of mann whitney $u$ test, $u$ count $=313.5$ were smaller than $u$ table 526 , so there was a significant difference between two classes, with a higher mean rank in ICBA. However students on ICBA were identified as having a specific misconception (SM) on several concepts of corrosion. The percentage of students on ICBA who have SM on the concept of voltaic series, prediction of metal rust, prevention of corrosion through metal coating, and cathodic protection were 46.67\%, 46.67\%, 66.67\%, and 56.67\%. The analog concept is not well understood by students, so potentially brings up SM. Analogies requires the students' reason ability, because students conclude the submicroscopic aspects of corrosion through analyzing similarity and difference between analogous concept and target concept. In other words, analogy learning was giving submicroscopic aspect by indirect visualization. The results of other researches indicate that the reasoning ability of high school students is still low. The reasoning process requires students' ability to analyze and conclude submicroscopic aspects of corrosion topic. A literation study of the reasoning ability of high school students is needed to explain the occurrence of SM, even though they have been given indirect visualization by analogy.
\end{abstract}

Keywords-Analogy, Misconception, Reasoning Ability, Corrosion

\section{INTRODUCTION}

Corrosion is an applicative topic which can be useful for students to explain everyday life phenomenon. Student's knowledge can be used to predict the rate of metal corrosion and corrosion prevention. Corrosion is product of reaction between ferrum and oxygen gas or water vapor or acidic substances, which is classified as spontaneous redox reactions [1]. Spontaneous of electrons flow from anode to cathode, can produce iron (III) oxide or rust which increase on metal mass. Students observed iron rust's color is reddish brown. Johnstone explains that there are three representation of chemical knowledge which are described as triangles:

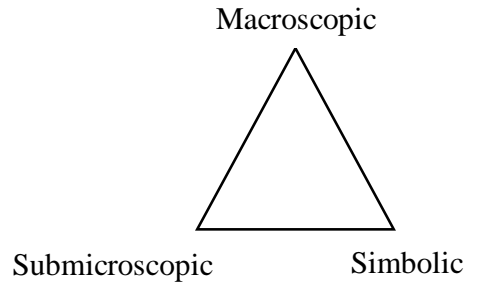

Fig 1. Johnstone's triangle representation of Chemistry [2]

The macroscopic aspect on the peak of the triangle, because students can understand it by observing. Whereas submicroscopic and symbolic aspects can be used to explain macroscopic aspects. So the submicroscopic and symbolic aspects require students' depth understanding. Submicroscopic representation is independently interpreted by students which can not observed as particulate phenomena, for example electron flow [3]. Rust observed reddish brown as product of redox reaction which has spontaneous electrons flow (submicroscopic aspect). This submicroscopic phenomenon is formulated on chemical reaction equations. The equation reaction of ferrum and oxygen gas / water vapor produce iron(III) oxide as a symbolic aspect.

Onwu concluded that students have difficulty to connect macroscopic and submicroscopic, because student' inconsistently reasoning to interpret particulate phenomena [4]. This is contrary to Piaget's cognitive development theory which high school students had formal thinking [5], which students built independent interpretation of the phenomenon which can not observed (submicroscopic). The factor can affect lower formal thinking ability which is conventional learning process does not involve students' activity [6]. This is supported by misconception finding of saveral researches on the topic which are full of submicroscopic representations. 
Barke, et. al found students' misconceptions about reaction of iron-copper(II) sulfate. Students' perceptions that nails absorb $\mathrm{Cu}$ atoms and electrons from $\mathrm{CuSO}_{4}$ solution, so the surface of nail was coated by copper [7]. Karamustafaglou also identified students' misconception that electrons flow from the cathode to the anode through electrolyte solution [8]. This topic which contains submicroscopic aspects can cause misconceptions.

Learning corrosion requires a strategy to visualize submicroscopic aspects which is analogy. The analogy is giving a familiar phenomenon that can be observed by students in the surrounding environment, so easier to understand submicroscopic aspects [9]. Analogy of Waterfall flow can be used to visualize the spontaneous electron flow in the corrosion topics [10]. The analogy is presented by analog concept and target concepts descriptions, with the similarities and differences of both concepts. Description of the similarities and differences of both concepts which can minimize students' misconceptions occurence.

Analogy provides an indirect visualization of submicroscopic aspects, so that students develop independent interpretations of submicroscopic aspects through closed interrelations between analog concepts and target concepts [11]. This involves students to think actively to make interpretation of submicroscopic aspects based on analog concepts that which are familiar to them. When students think actively, they are in the reasoning process, so the both of thinking process are correlated [12]

Lawson states that the reasoning process which involves observing facts, information (experts' opinion), and experience can used for formulating conclusion [13]. Students' thinking ability in interpreting submicroscopic aspects is required on analogy learning. The ability to interpret submicroscopic aspects which involves students' reasoning ability [14], [15]. Students' reasoning ability can provide two possible impacts which are to reach true understanding or misconception of submicroscopic phenomenon.

Based on that description, we needed to do research to exam differences students' conceptual understanding by learning analogy (ICBA) and without analogy (ICWA). The students' misconception will be analyzed based on review of students' reasoning abilities and relevant of research results.

\section{METHODS}

This research was done on two classes of grade $12^{\text {th }}$ science students of SMAI Yakin Tutur Nongkojajar Pasuruan. This research design used quasy experimental which was posttest only control group design:

TABLE 1. RESEARCH DESIGN

\begin{tabular}{clc}
\hline Class & \multicolumn{1}{c}{ Experiment } & Result \\
\hline ICBA & $\begin{array}{l}\text { Inquiry learning by } \\
\text { analogy }\end{array}$ & $\begin{array}{c}\text { Conceptual } \\
\text { Understanding }\end{array}$ \\
\hline ICWA & $\begin{array}{l}\text { Inquiry learning } \\
\text { without analogy }\end{array}$ & \\
\hline
\end{tabular}

Conceptual understanding is measured by a three-tier instrument [16] with the category of Certainty of Respond Index $(\mathrm{CRI}) \leqslant 2$ categorized as less sure [17], which divide into five categories are sound understanding (SU), partial understanding (PU), partial understanding with specific misconcenption (PUSM), specific misconception (SM), dan no understanding (NU). This instrument can distinguish students who had misconceptions and lack knowledge. This modification matrix to determines the level of conceptual understanding:

TABLE II. CONCEPTUAL UNDERSTANDING LEVEL

\begin{tabular}{|c|c|c|}
\hline Level & Category & Descriptions \\
\hline 4 & SU & $\begin{array}{l}\text { tier } 1 \text { and tier } 2 \text { true } \\
\text { high confidence }\end{array}$ \\
\hline 3 & PU & $\begin{array}{l}\text { tier } 1 \text { and tier } 2 \text { true } \\
\text { lower confidence }\end{array}$ \\
\hline 2 & PUSM & $\begin{array}{l}\text { tier } 1 \text { true and tier } 2 \text { false } \\
\text { lower confidence } \\
\text { tier } 1 \text { false and tier } 2 \text { true } \\
\text { lower confidence }\end{array}$ \\
\hline 1 & SM & $\begin{array}{c}\text { tier } 1 \text { true and tier } 2 \text { false } \\
\text { high confidence } \\
\text { tier } 1 \text { false and tier } 2 \text { true } \\
\text { high confidence } \\
\text { tier } 1 \text { false and tier } 2 \text { false }\end{array}$ \\
\hline & & high confidence \\
\hline 0 & NU & $\begin{array}{c}\text { tier } 1 \text { false and tier } 2 \text { false } \\
\text { lower confidence }\end{array}$ \\
\hline
\end{tabular}

The conceptual understanding scores were prerequisites test and inferential test to justify the existence of significant differences conceptual understanding both of the classes. Then it was descriptivelly analyzed by percentage of students in each understanding level:

$\%$ Students on level $1(S M)=\frac{\sum S M(S U)}{\sum \text { total of students }} \times 100 \% \ldots . .(5)$

\section{RESULT}

The conceptual understanding data described that both classes have homogeneous variance, but have an abnormal distribution. This research used nonparametric inferential test which was the whitney $u$ test showed that the value of $\boldsymbol{U}_{\text {count }}=\mathbf{3 1 3 , 5}$ is lower than $\boldsymbol{U}_{\text {table }}=\mathbf{5 2 6}$, so there is a significantly differences of conceptual understanding between ICBA (mean rank= 35,5) and ICWA (mean rank $=25,95$ ). So that Students' conceptual understanding of ICBA is better than ICWA.

However, we descriptively analyzed the categories of students' understanding, gave results that were in contrast with the findings of classical understanding. Following is the percentage of total number students who had misconceptions on the topic of corrosion: 


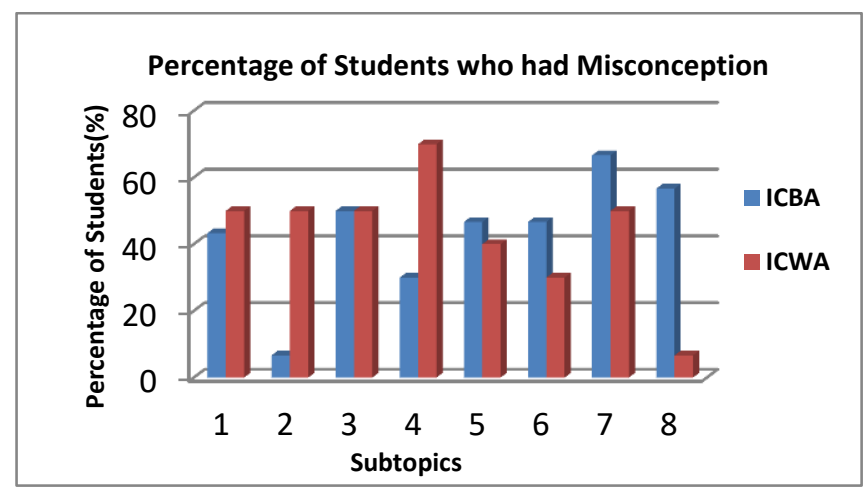

Fig 2. Diagram of Percentage of students who had misconception on both classes

Based on the diagram, describes that students' misconceptions on ICBA were higher than ICWA in subtopics 5 until 8 . The sequentially subtopics are voltaic series, prediction of metal rust, metal coating, and cathodic protection. ICBA students who received visualization, theoritically they will be easier to understand submicroscopic aspects. However, research findings show contrast on saveral subtopics. The following is students' misconceptions which were identified:

TABLE III. THE FINDINGS OF STUDENTS' MISCONCEPTIONS

\begin{tabular}{l} 
Students' Misconceptions \\
Voltaic series \\
1. The standard reduction potentials of a metal are sorted by \\
decreasing reactivity \\
2. The voltaic series are sorted by the quantity of the standard \\
reduction potential value and does not relate to the reducing \\
or oxidizing agent \\
Prediction of Metal Rust \\
1. Electrons flow in electrolyte solution, because they are \\
attracted by $\mathrm{H}^{+}$ions. Electrons from anode will be carried \\
by $\mathrm{H}^{+}$ions to the cathode \\
2. Corrosion process occurs faster when the metal is contacted \\
to $\mathrm{O}_{2}$ gas or $\mathrm{O}_{2}$ dissolved in $\mathrm{H}_{2} \mathrm{O}$ \\
\hline Metal Coating and Protection of Chatodic \\
3. In all experiments, the nail always acts as a cathode and \\
other metals as an anode, so that other metals will be more \\
easily oxidized based on the standard reduction potential \\
which has smaller value than nail \\
Positive standard reduction potential means that the \\
reduction reaction is spontaneously occurred and the \\
negative standard reduction potential is a non-spontaneous \\
reduction reaction, so corrosion process will be quickly \\
occurred
\end{tabular}

Students' misconceptions occur in subtopics that contain submicroscopic aspects, are electron flow, meaning of voltaic series based on quantity and determination spontaneity of reaction, corrosion triggers, and determination of cathode anodes (prevention of corrosion). There is required to brief describe the analogy used in this research:

TABLE IV. ANALOGIES WHICH ARE USED IN THIS RESEARCH

\begin{tabular}{|c|c|c|}
\hline No & Target Concept & Analog Concept \\
\hline 1 & $\begin{array}{l}\text { Spontaneous electron } \\
\text { flow based on cell } \\
\text { potential value }\end{array}$ & $\begin{array}{l}\text { Waterfalls flow from the } \\
\text { higher flatland to the lower } \\
\text { flatland, because differences } \\
\text { on gravitation potential } \\
\text { energy [10] }\end{array}$ \\
\hline 2 & $\begin{array}{l}\text { Effect of potential cell } \\
\text { value on spontaneity of }\end{array}$ & $\begin{array}{l}\text { i. The flow of the waterfall } \\
\text { occurs spontaneously to go }\end{array}$ \\
\hline
\end{tabular}

\begin{tabular}{|c|c|c|}
\hline No & Target Concept & Analog Concept \\
\hline & $\begin{array}{l}\text { electron flow in redox } \\
\text { reactions }\end{array}$ & $\begin{array}{l}\text { a lower flatland, because } \\
\text { the gravitational potential } \\
\text { energy is positive [10] } \\
\text { ii. Stagnant water in the low } \\
\text { lands does not } \\
\text { spontaneously go up } \\
\text { (water flows up), because } \\
\text { the value of gravitation } \\
\text { potential energy is } \\
\text { negative }\end{array}$ \\
\hline 3 & $\begin{array}{l}\text { The Effect corrosion } \\
\text { on surface structure of } \\
\text { metals }\end{array}$ & $\begin{array}{l}\text { A person infected by a virus } \\
\text { TB who will tend to have a } \\
\text { thin body and not powered }\end{array}$ \\
\hline 4 & $\begin{array}{l}\text { The difference on } \\
\text { corrosion tendency of } \\
\text { nail which its surface } \\
\text { are stretched and not } \\
\text { stretched }\end{array}$ & $\begin{array}{l}\text { The chance of getting a } \\
\text { disease depends on condition } \\
\text { of the body. Active smokers } \\
\text { are easier to get TBC than } \\
\text { passive smokers, because } \\
\text { active smokers' lungs are less } \\
\text { healthy (destructed) }\end{array}$ \\
\hline 5 & $\begin{array}{l}\text { Protection of chatodic } \\
\text { is a way to prevent } \\
\text { corrosion }\end{array}$ & $\begin{array}{l}\text { The body can be protected } \\
\text { from TBC when we have } \\
\text { been vaccinated and did } \\
\text { healthy lifestyle }\end{array}$ \\
\hline
\end{tabular}

The analogies were validated by lecturer who experts in learning and other lecturer who experts in chemistry, then the ruslt is a high validity category. So the analogy can be able to visualize submicroscopic aspects of the target concept. The following is an example of a description of the similarities and differences between the target concept and the analog concept:

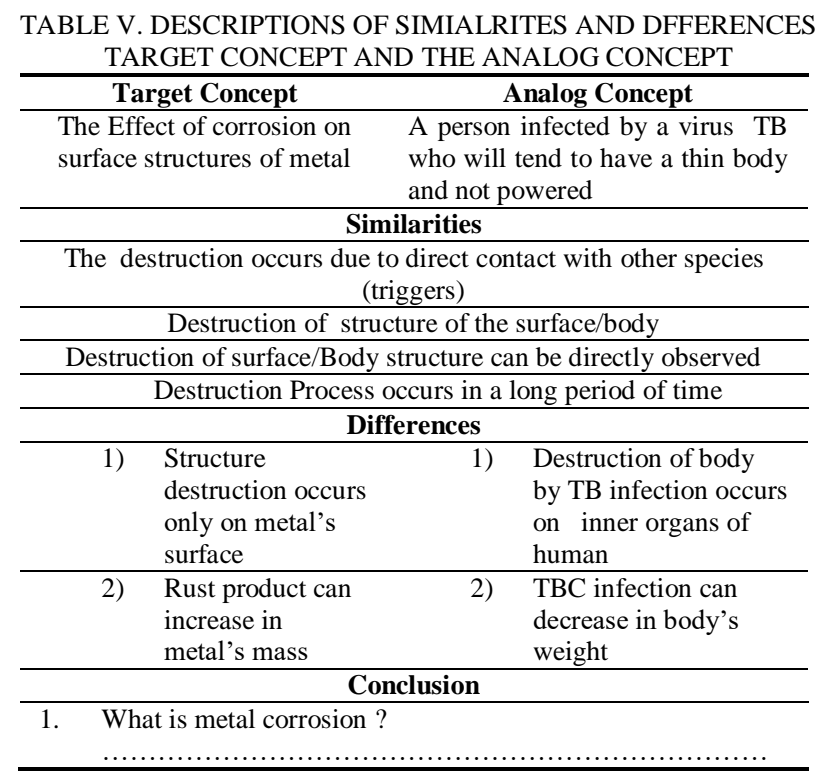

The characteristic of analogy learning provides indirect visualization. Students are involved in analysing the similarities and differences between target concept and analog concept then formulating conclusion of the concept. The students' thinking process are remembering the familiar analog, then connecting to the target concept and concluding which are reasoning process. The Research Bao, et al concluded that the content knowledge does not affect students' reasoning abilities at certain period of time [19]. The student's reasoning ability is specific for individual and naturally occured. Every student has different 
reasoning ablility. But problem is whether the students' reasoning ability is sufficient or not to be able abstracting submicroscopic aspect through analog concept.

Purwana, et al concluded that students' initial competency of reasoning ability had low category, so they required guidance in the process of concrete and abstract reasoning [13]. This is similarly found by Utama, et al, that the low reasoning ability which affects students were difficult to understand abstract concepts [20]. This can be used as a reference to explain the occurrence of students' misconceptions in ICBA even though they had been indirectly visualization through analogy. Students' reasoning ability can influence their potential misconceptions when analogy has been given. The following chart shows the students' reasoning ability in analogy learning process:

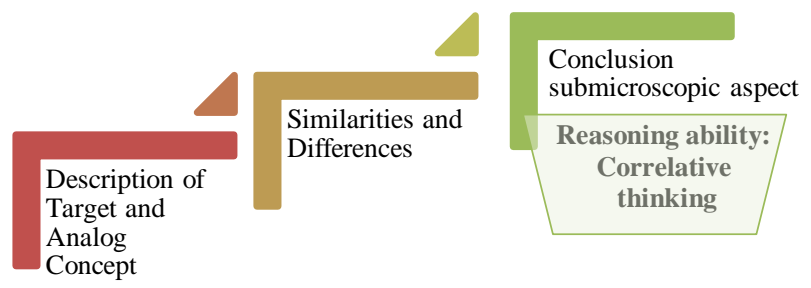

Fig 3. The Sudents' Reasoning Ability in Analogy Learning Process

Lawson divides six aspects of reasoning ability, that are concentration of matter and volume, proportional thinking, identification and control of variables, probabilistic thinking, correlative thinking, and hypothetic-deductive thinking [21]. Measurements on the six aspects of reasoning ability can be done through the Lawson Test of Scientific Reasoning-LCTSR instrument. The accumulation scores of the six aspects are used to determine the categories of students' reasoning ability which is including concrete, transitional, or formal reasoning. High reasoning ability when it has formal category which means students are able to do abstraction of submicroscopic aspects. However, this research does not measure how much students' reasoning ability, but explain based on literature review.

But the aspect of students' reasoning ability which gave big contributing in understanding analogy is correlative thinking. Correlative reasoning ability is important role when students relate two variables which are analog concept and target concept. Description of the similarities and differences can help students to interpret of submicroscopic aspects. But the results of previous researches concluded that the students' reasoning ability had low and do not reach the formal category.

\section{CONCLUSION}

Analogy learning can potentially lead misconceptions if students have low reasoning ability. Students' reasoning ability are required to construct interpretations of submicroscopic aspects, based on target concepts and analog concepts along through description of similarities and differences. Analogy gives indirect visualization to students, so that it requires students' focus and reasoning ability.

Future researches require to capture students' reason ability by using LCSTR instruments. The aims to determine the tendency of students' reasoning ability. Before analogy learning begins, It is necessary to measure students' reasoning ability as one aspect that influences students' conceptual understanding. Students had been difficulty understood submicroscopic aspects through descriptive analogy, it is necessary for further research to test the effectiveness of the pictorial analogy.

\section{REFERENCES}

[1] Chang, R. \& Overby, J. 2011. General Chemistry The Essential Concept. New York: McGraw-Hill Companies.

[2] Taber, K. 2009. Challenging Misconceptions in the Chemistry Classroom: Resources to Support Teachers. Educació Química EduQ, 4, 13-20.

[3] Johnstone, A., H. 1993. The Development of Chemistry Teaching: A Changing Response to Changing Demand. Journal of Chemical Education, 70(9)

[4] Onwu, G \& Randall, E. 2006. Some aspects of students' understanding of a representational model of the particulate nature of matter in chemistry in three different countries, Chem. Educ. Res. Pract., Vol 7, Issue 4,pp. 226-239.

[5] Suparno, Paul. 2001. Teori Perkembangan Kognitif Jean Piaget. Yogyakarta: Kanisius.

[6] Winarti, A. 1998. Analisis Pemahaman Konsep Asam Basa melalui Penggambaran Mikroskopis dan Hubungannya dengan Kemampuan Berpikir Formal Mahasiswa Program Studi Pendidikan Kimia FKIP UNLAM Banjarmasin. Tesis tidak diterbitkan. Malang: Institut Keguruan dan Ilmu Pendidikan Malang

[7] Barke, H.D., Al Hazari, \& Yitbarek, S., 2009, Misconceptions in Chemistry, Berlin: Springer Link.

[8] Karamustafaoglu, S. dan Mamlok-Naman, R, 2015, Understanding Electrochemistry Concepts Using The Predict-Observe-Explain Strategy. Eurasia Journal of Mathematics, Science \& Technology Education, Vol 11, No 5, pp. 923-936.

[9] Harrison, A., G. \& Treagust, D., F, 2006, Teaching And Learning With Analogies: Friend or Foe?, Metaphor and Analogy in Science Education, pp. 11-24.

[10] Effendy. 2012. A Level Chemistry for Senior High School Students Volume 3. Malang: Indonesian Academic Publishing.

[11] Thiele, R.B \& Treagust, D.F, 1994, The nature and extent of analogies in secondary chemistry textbooks, Vol 22, Issue 1, pp 61-74

[12] Bybee, R.,\&Fuchs, B, (2006), Preparing the 21st century workforce: a new reform in science and technology education. Journal of Research in Science Teaching, Vol 43, No 4, pp. 349-352.

[13] Purwana, U, Liliasari, \& Rusdiana, D, 2016, Profil Kompetensi Awal Penalaran Ilmiah (Scientific Reasoning) Mahasiswa pada Perkuliahan Fisika Sekolah, prosiding SNIPS 2016

[14] Sirhan, G, 2007, Learning Difficulties in Chemistry: An Overview. Journal of Turkish Science Education, Vol 4, No 2

[15] Santos, V.C \& Arroio, A, 2016, The representational levels: Influences and contributions to research in chemical education, Vol 13, No 1,pp 318.

[16] Schaffer, D. L. 2013. The Development and Validation of A ThreeTier Diagnostic Test Measuring Pre-Service Elementary Education and Secondary Science Teachers' Understanding Of The Water Cycle. Disertasi diterbitkan. University of Missouri: The Faculty of the Graduate School.

[17] Hakim, A., Liliasari, \& Kadarohman, A. 2012. Student Concept Understanding of Natural Products Chemistry in Primary and Secondary Metabolites Using the Data Collecting Technique of Modified CRI. International Online Journal of Educational Sciences, Vol 4, No 3,pp. 544-553

[18] Tural, G. 2015. Cross-Grade Comparison of Students' Conceptual Understanding with Lenses in Geometric Optics. Science Education International, Vol 26, No 3, pp. 325-343.

[19] Bao, L, Fang, K, \& Cai, T, 2018d, Learning of Content Knowledge and Development of Scientific Reasoning Ability: A Cross Culture 
Comparison, American Journal of Physics, Vol 77, Issue 12, pp. 11181123

[20] Utama, Z.P, Maison, \& Syarkowi, A, 2018, analisis kemampuan bernalar siswa sekota Jambi, Vol 9, No 1, pp 1-5.

[21] Lawson, A.E. 2008. What are Null Hypotheses? The Reasoning Linking Scientific and Statistical Hypothesis Testing. Science Education Review, 7(3). 